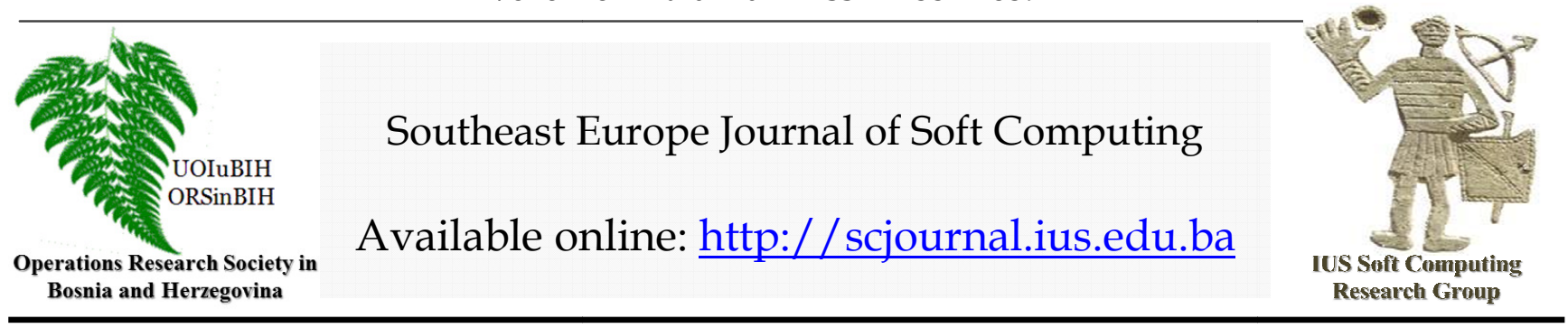

\title{
The Analysis of Transformational Leadership Behaviors and Their Relation with Organizational Commitment
}

\author{
Gökçe Demir \\ International University of Sarajevo, \\ Faculty of Engineering and Natural Sciences, \\ HrasnickaCesta 15, Ilidža 71210 Sarajevo, \\ Bosnia and Herzegovina \\ 150102161@students.ius.edu.ba
}

\author{
Article Info \\ Article history: \\ Article received on 17 Jan. 2017 \\ Received in revised form 17 Feb.2017 \\ Keywords: \\ Transformational Leadership, \\ Managers, Teachers, \\ Organizational Commitment, \\ High Schools.
}

\begin{abstract}
This study aims to analyze transformational leadership behaviors and its relation with organizational commitment in high school managers and teachers in Istanbul, Turkey. The effect of transformational leadership on organizational commitment was investigated in the study. In this context, some research questions were created and a literature review was performed. Some specific hypothesis statement was developed, tested, and finalized. Quantitative research design was applied in this research with cross-sectional time frame. Convenience sampling method was used in the study. Data was obtained from 135 participants. The population of the study comprised teachers, principals, study program coordinators, managers, administrators and other staff from nine public high schools in Istanbul, Turkey. A structured self-completed quantitative research survey was conducted in this study which was distributed to the participants of the study and collected in two months. The main research instrument for data collection in this study was a survey with five descriptive and 11 inferential statistics questions. In this research, quantitative survey was the main instrument for primary data collection which was designed in a "5" and "7" - point Likert's scale. The data was analyzed with SPSS (Statistical Package for the Social Sciences) version 20. The research questions and a hypothesis were developed for the study which were tested with Chi square, correlations, and t-test. Null hypothesis (H0) was rejected $(\mathrm{p}<0.05)$ and so, the study found that transformational leadership of high school managers is significantly related to affective commitment of high school teachers in Istanbul.
\end{abstract}

\section{INTRODUCTION}

The concepts of leadership and organizational commitment are among the most important and prominent topics in the management area, especially by the increase of number of studies in recent years. Human is the most important factor for all of organizations and people have an obligation to get organized to fulfill their needs and achieve their goals as well. Global developments have caused a development of new leadership styles in accord with the existed situation. As a result, theoretical and practical leadership studies increase from day to day (Eren, 1998).

Many people among the ones who deal with the field of leadership theory and its applications suggest the leadership model which inspires today's management 
employees and provides them radical changes. The transformational leadership approach refers that leaders need to act in some certain behaviors in realizing the complex applications of the organizational structure. It is definitely difficult to express leaders' attitudes and behaviors with a few of dimensions for which they are supposed to act in different situations. There is the need of many factors to create a new vision to struggle with such an environment full of threats which is forming the general framework of globalization. Transformational leadership deals with leaders' performance and success more than their personal characteristics and employees' reactions (Iscan, 2002).

Environmental change, uncertainty, and chaos make today's business managers faced with unresolved issues. Structural changes in economic and political system, and technological improvements make it difficult for managements to adapt these changes with existing methods and implementations, or even make it impossible. Transformational management is an effective way for activating and restructuring the organization in response to radical changes of external environment. Transformational management in management area is related to the top management. Consequently, there is a need of top managers in supporting radical changes to prepare necessary organizational conditions and manage these conditions effectively. However, the commitment of top managers to the past might cause the management to lose its flexibility by remaining unresponsive to the changing conditions (Tichy, 1996).

Organizational commitment is the adaptation of commitment sense to the worker as the result of performed activities to keep maintenance of the organization. The worker who internalizes feeling of organizational commitment gets satisfied of his/her work. He/she also conforms to the organization (Bayram, 2005). Organizational commitment has a psychological dimension and it is formed through dealing with the relation between workers and organizations. An individual decides to stay or not in his/her organization as the result of the formation (Allen \& Meyer, 1996).

Even though organizational commitment which is among attitudes of employees is a prominent issue, especially after 1970s, there is not a consensus for the description of it. There are various kinds of definitions of organizational commitment in literature. For instance, Morrow said that there are around 30 different definitions about organizational commitment in literature (Col, 2004).

Employee commitment has been among the remarkable topics for both researchers and managers since 1960s (Sulliman\& Iles, 2000). The concept of organizational commitment has got popularity over the past two decades in the industrial and organizational psychology literature. Some of the studies demonstrated that occupational commitment would increase performance while it decreases absenteeism and quitting the job. The commitment is mentioned with concepts such as career, norms, identification, moral values, occupation, job description, security and other related variables. The concept of organizational commitment has become the focus point of many empirical studies (Tayyah\& Tariq, 2001).

Employees with commitment work hard, keep staying in the organization and contribute to the development of the organization in the theory. Mowday et al. claim that commitment is more than a passive loyalty to the organization and it has an active relation between the organization and individuals who make great efforts to increase the reputation of the organization (Slocombe\& Dougherty, 1998).

Organizations which have employees with a higher level of commitment are more efficient. Because, employees with strong commitment have a lower level of possibility of negative behaviors such as absenteeism, being late to work, and quitting the job as a comparison to employees with a lower level of commitment. Individuals who internalize organizational goals and make an over effort to achieve them increase the competitive power of the organization. Moreover, employees with high commitment help to increase reputation of their organizations. This, therefore, helps to take attention of qualified employees (Angle \& Perry, 1981; Cengiz, 2000).

\section{METHODOLOGY}

\subsection{Research Purpose}

The purpose of this study is to analyze transformational leadership behaviors and their relation with organizational commitment in high school managers and teachers in Istanbul, Turkey.

The primary research questions of the study are as follows:

a. Does transformational leadership have the effect on affective commitment?
b. What is the relationship between transformational leadership and affective commitment?

Furthermore, the hypotheses of the research are developed as follows:

$H_{0}$ : Transformational leadership of high school managers is not significantly related to affective commitment of high school teachers in Istanbul.

$H_{1}$ : Transformational leadership of high school managers is significantly related to affective commitment of high school teachers in Istanbul.

\subsection{Instruments}

A demographic survey was created and two data collection instruments were applied for the study. The Multifactor Leadership Questionnaire Rater Form (5x-Short) was used to assess transformational leadership of managers as how teachers perceive them (Avolio \& Bass, 2004) while the Organizational Commitment Questionnaire was used to measure affective commitment of teachers (Meyer, Allen \& Smith, 1993).

The Multifactor Leadership Questionnaire (MLQ) Rater Form (5x-Short) is one of the measuring instruments for 


\section{G. Demir/ Southeast Europe Journal of Soft Computing Vol.5 No.1 March 2016 (51-57)}

the study to assess transformational leadership of managers through the perception of teachers. The MLQ Form 5-X Rater is developed by Bass \& Avolio (2004). The questionnaire (Cronbach`s alpha $=0.95$ ) was adapted in Turkish language by Cemaloglu (2007). The MLQ was first developed in 1985 (Saglam, 2008).

\subsection{Sampling and Procedures}

The purpose of this study was to analyze transformational leadership behaviors and their relation with organizational commitment in high school managers and teachers. The data for the study was gathered from a total of 135 respondents.

In this research, both primary data and secondary data were used. And quantitative research design was applied in this research. The research was conducted in a crosssectional time frame. Convenience sampling method was used in the study. The main instrument for data collection was a survey and descriptive statistics questions were also applied. Data was analyzed with SPSS (Statistical Package for the Social Sciences) version 20.

\subsection{Demographic Results}

The target population of this study was high school managers and teachers in Istanbul, Turkey. Questionnaires were randomly distributed to 9 government high schools in Istanbul and a total of 135 surveys were collected among staves of these schools. The figure for gender of respondents is presented as follows:

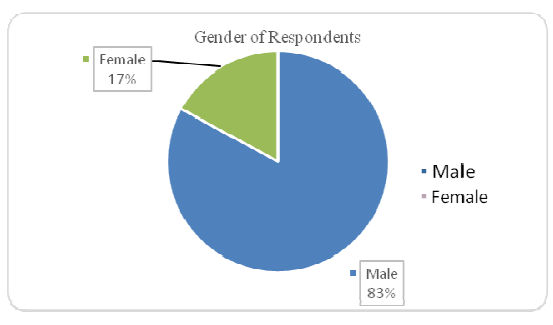

Figure 1. Percentage of Participants with Respect to Gender $(\mathrm{N}=135)$

This figure represents the percentage of participants with respect to their gender. 23 of the participants from selected high schools are female while 112 of them are male which means $17 \%$ of the participants are female and $83 \%$ of them are male.

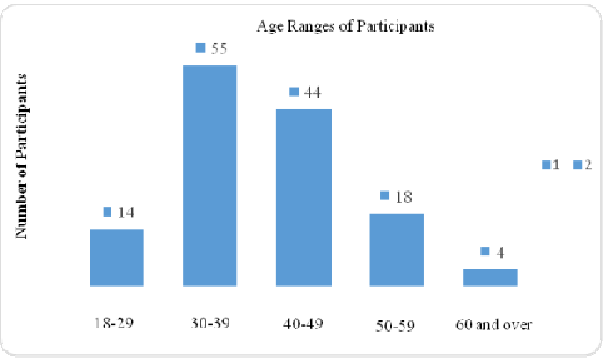

Figure 2. Age Ranges of Participants

This figure represents age ranges of participants. 14 of them are between 18-29 years old, 55 of them are between
30-39 years old, 44 of them are between 40-49 years old, 18 of them are between 50-59 years old, and 4 of the participants are 60 and over.

Table 1. Respondents' Gender Breakdown

\begin{tabular}{|l|l|l|}
\hline Gender & Frequency & Percent \\
\hline Female & 23 & 17,0 \\
\hline Male & 112 & 83,0 \\
\hline
\end{tabular}

As it is presented in the table above, out of 135 participants $23(17 \%)$ were female and $112(83 \%)$ of participants were male.

Table 2. Respondents' Age Breakdown

\begin{tabular}{|l|l|l|}
\hline Age & Frequency & Percent \\
\hline $18-29$ & 14 & 10,0 \\
\hline $30-39$ & 55 & 41,0 \\
\hline $40-49$ & 44 & 33,0 \\
\hline $50-59$ & 18 & 13,0 \\
\hline 60 and over & 4 & 3,0 \\
\hline
\end{tabular}

This table presents age range breakdown. According to it, out of 135 participants 14 (10\%) were grouped into 18-29 age range, $55(41 \%)$ of participants belonged to $30-39$ age range, $44(33 \%)$ of them belonged to $40-49$ age bracket while $18(13 \%)$ belonged to 50-59 age range and $4(3 \%)$ of survey respondents were 60 and over.

Table 3. Professional Position of Survey Respondents

\begin{tabular}{|l|l|l|}
\hline Professional position & Frequency & Percent \\
\hline Teacher & 90 & 66,7 \\
\hline Principal & 3 & 2,2 \\
\hline Manager & 12 & 8,9 \\
\hline Coordinator & 5 & 3,7 \\
\hline Administrator & 11 & 8,1 \\
\hline Other & 14 & 10,4 \\
\hline
\end{tabular}

Table 3 presents professional position of survey respondents. According to the table, out of 135 survey respondents $90(66,7 \%)$ were teachers, $3(2,2 \%)$ were principals, $12(8,9 \%)$ were managers, $5(3,7 \%)$ were coordinators, $11(8,1 \%)$ were administrators and $14(10,4)$ of survey respondents belonged to the category of others.

Table 4. Educational Level of Participants

\begin{tabular}{|l|l|l|}
\hline Educational level & Frequency & Percent \\
\hline Some college & 13 & 9,6 \\
\hline Bachelor's degree & 78 & 57,8 \\
\hline Master's degree & 43 & 31,9 \\
\hline PhD & 1 & 0,7 \\
\hline
\end{tabular}

Table-4 represents educational level of participants. Out of 135 participants $13(9,6 \%)$ had some college education level, $78(57,8 \%)$ of them had Bachelor's degree while 43 


\section{G. Demir/ Southeast Europe Journal of Soft Computing Vol.5 No.1 March 2016 (51-57)}

$(31,9 \%)$ of survey respondents had Master's degree and 1 $(0,7)$ had $\mathrm{PhD}$.

Table 5. Working Experience at the Current Organization

\begin{tabular}{|l|l|l|}
\hline Years & Frequency & Percent \\
\hline $0-9$ & 74 & 55,0 \\
\hline $10-19$ & 44 & 32,0 \\
\hline $20-29$ & 16 & 12,0 \\
\hline 30 and over & 1 & 1,0 \\
\hline
\end{tabular}

Table-5 presents working experience at the current organization. Out of 135 respondents $74(55 \%)$ belonged to $0-9$ years range of work experience with the current organization while $44(32 \%)$ of them belonged to $10-19$ range, $16(12 \%)$ of respondents indicated 20-29 years of work experience with the current organization and $1(1 \%)$ respondent belong to 30 and over bracket for years with the current organization.

\section{RESULTS}

In this part of this study hypothesis testing is done and research questions are analyzed. For this purpose, Chi Square Frequencies Output, Correlations, and t-test results are given place and explained as follows:

Table 6. Chi-Square Frequencies Output

\begin{tabular}{|c|c|c|c|c|c|c|c|c|c|c|c|}
\hline & 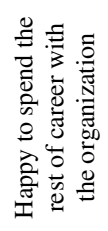 & 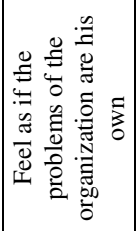 & 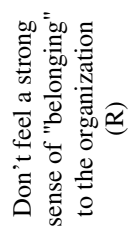 & 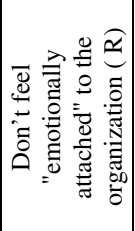 & 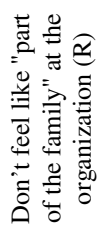 & 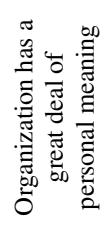 & 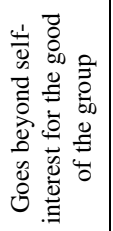 & 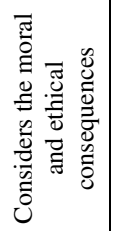 & 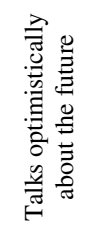 & 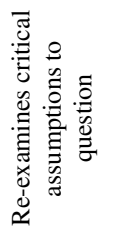 & 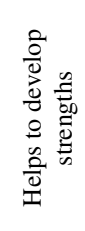 \\
\hline $\begin{array}{l}\text { Chi-Square } \\
\text { Coefficient }\end{array}$ & 39.793 & 182.074 & 106.785 & 122.237 & 130.948 & 109.274 & 60.222 & 78.244 & 45.259 & 84.074 & 62.000 \\
\hline $\begin{array}{l}\text { Degree of fredom } \\
\text { (df) }\end{array}$ & 6 & 6 & 6 & 6 & 6 & 6 & 4 & 3 & 4 & 4 & 4 \\
\hline $\begin{array}{l}\text { Significance } \\
\text { p-value }\end{array}$ & 0.000 & 0.000 & 0.000 & 0.000 & 0.000 & 0.000 & 0.000 & 0.000 & 0.000 & 0.000 & 0.000 \\
\hline
\end{tabular}

*df (Degree of Freedom) represents the number of transformational leadership and organizational commitment items.

Reporting the analysis results:

$H_{0}$ : Rejected in favor of $\mathrm{H} 1$.

$H_{1}$ : Transformational leadership of high school managers is significantly related to affective commitment of high school teachers in Istanbul.

In table-6, it is indicated that the significance value (0.000) is less than the usual threshold value of 0.05 . It suggests that the null hypothesis, $H_{0}$ (transformational leadership of high school managers is not significantly related to affective commitment of high school teachers in Istanbul), can be rejected in favor of the alternate hypothesis, $H_{l}$ (transformational leadership of high school managers is significantly related to affective commitment of high school teachers in Istanbul).

Table 7. Correlations

\begin{tabular}{|c|c|c|c|c|c|c|}
\hline & & $\begin{array}{l}\text { Goes beyond self- } \\
\text { interest for the good of } \\
\text { the group }\end{array}$ & $\begin{array}{l}\text { Considers the moral } \\
\text { and ethical } \\
\text { consequences }\end{array}$ & $\begin{array}{l}\text { Talks optimistically } \\
\text { about the future }\end{array}$ & $\begin{array}{l}\text { Re-examines critical } \\
\text { assumptions to } \\
\text { question }\end{array}$ & $\begin{array}{l}\text { Helps to develop } \\
\text { strengths }\end{array}$ \\
\hline \multirow{2}{*}{$\begin{array}{l}\text { Happy to spend the } \\
\text { rest of career with } \\
\text { the organization }\end{array}$} & $\begin{array}{l}\text { Correlation } \\
\text { coefficient }\end{array}$ & $.552^{* *}$ & $.490^{* * *}$ & $.586^{* *}$ & $.538^{* * *}$ & $.609^{* * *}$ \\
\hline & significance $\mathrm{p}$-value & 0.000 & 0.000 & 0.000 & 0.000 & 0.000 \\
\hline \multirow{2}{*}{$\begin{array}{l}\text { Feel as if the } \\
\text { problems of the } \\
\text { organization are his } \\
\text { own }\end{array}$} & $\begin{array}{l}\text { Correlation } \\
\text { coefficient }\end{array}$ & $.533^{* *}$ & $.664^{* * *}$ & $.521^{* *}$ & $.503^{* * *}$ & $.584^{* * *}$ \\
\hline & significance $\mathrm{p}$-value & 0.000 & 0.000 & 0.000 & 0.000 & 0.000 \\
\hline \multirow{2}{*}{$\begin{array}{l}\text { Don't feel a strong } \\
\text { sense of "belonging" } \\
\text { to the organization } \\
\text { (R) }\end{array}$} & $\begin{array}{l}\text { Correlation } \\
\text { coefficient }\end{array}$ & $.646^{* * *}$ & $.578^{* * *}$ & $.605^{* *}$ & $.563^{* * *}$ & $.665^{* *}$ \\
\hline & significance p-value & 0.000 & 0.000 & 0.000 & 0.000 & 0.000 \\
\hline \multirow{2}{*}{$\begin{array}{l}\text { Don't feel } \\
\text { "emotionally } \\
\text { attached" to the } \\
\text { organization }(\mathrm{R})\end{array}$} & $\begin{array}{l}\text { Correlation } \\
\text { coefficient }\end{array}$ & $.648^{* * *}$ & $.578^{* *}$ & $.608^{* * *}$ & $.595^{* * *}$ & $.733^{* *}$ \\
\hline & significance p-value & 0.000 & 0.000 & 0.000 & 0.000 & 0.000 \\
\hline \multirow{2}{*}{$\begin{array}{l}\text { Don't feel like "part } \\
\text { of the family" at the } \\
\text { organization }(\mathrm{R})\end{array}$} & $\begin{array}{l}\text { Correlation } \\
\text { coefficient }\end{array}$ & $.590^{* * *}$ & $.531^{* *}$ & $.524^{* *}$ & $.595^{* *}$ & $.685^{* *}$ \\
\hline & significance $\mathrm{p}$-value & 0.000 & 0.000 & 0.000 & 0.000 & 0.000 \\
\hline \multirow{2}{*}{$\begin{array}{l}\text { Organization has a } \\
\text { great deal of } \\
\text { personal meaning }\end{array}$} & $\begin{array}{l}\text { Correlation } \\
\text { coefficient }\end{array}$ & $.638^{* * *}$ & $.601^{\text {*** }}$ & $.536^{* *}$ & $.670^{* * *}$ & $.620^{* * *}$ \\
\hline & significance p-value & 0.000 & 0.000 & 0.000 & 0.000 & 0.000 \\
\hline
\end{tabular}

** Correlation is significant at the 0.01 level (2-tailed). 


\section{G. Demir/ Southeast Europe Journal of Soft Computing Vol.5 No.1 March 2016 (51-57)}

Table-7 indicates that there is a significant relationship between transformational leadership and affective commitment because the Sig. 2-tailed level is 0.000 and the relationship is positive as it is seen in correlation coefficient values.

Table 8. Correlations

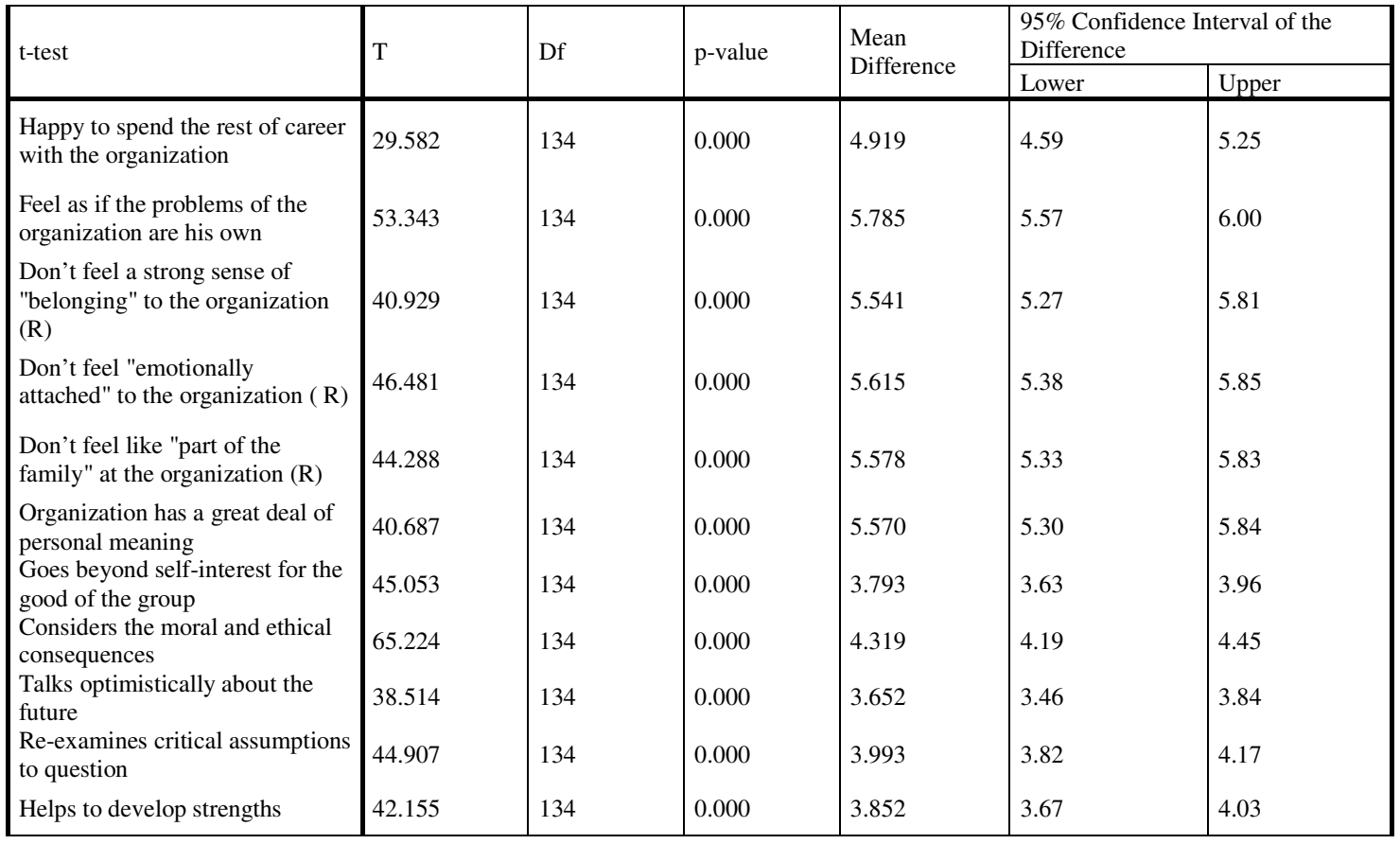

Table- 8 indicates t-test results.

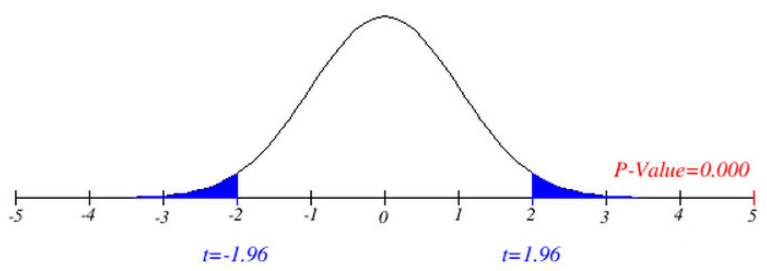

Figure 3. t-test Graph

According to the table, the null hypothesis is rejected, since $\mathrm{p}<0.05$.

So, there is a strong evidence that $(\mathrm{p}=0.000)$ transformational leadership of high school managers is related to affective commitment of high school teachers in Istanbul.

\section{CONCLUSION}

The purpose of this study was to analyze transformational leadership behaviors and its relation with organizational commitment in high school managers and teachers in Istanbul, Turkey. The questions of "Does transformational leadership have the effect on affective commitment?" and "What is the relationship between transformational leadership and affective commitment?" sought an answer for the aim of the study.
Male and female teachers and managers in 9 government high schools in Istanbul, Turkey, as a total of 135 survey respondents, constituted the population of the research which aimed to analyze the relationship between transformational leadership and affective commitment and measure its significance level.

The Multifactor Leadership Questionnaire Rater Form (5xShort) was used to measure transformational leadership of managers which was developed by Avolio \& Bass (2004) and the Organizational Commitment Questionnaires were used to measure affective commitment of teachers which were developed by Meyer, Allen \& Smith (1993). A demographic survey was also created.

The 5-point Likert's scale which was answered as '1: Not at all, 2: Once in a while, 3: Sometimes, 4: Fairly often, 5: Frequently, if not always is used for the Multifactor Leadership Questionnaire Rater Form (5x-Short). The affective commitment scale items of the Organizational Commitment Questionnaire with a 7 point Likert's scale ranging from: 1 for strongly disagree, 2 for disagree, 3 for slightly disagree, 4 for undecided, 5 for slightly agree, 6 for agree, 7 for strongly agree were used. 135 surveys received back which were distributed to 270 potential respondents in either paper or e-mail form.

The collected data which was gathered through questionnaire was analyzed by using SPSS software program and it was interpreted through Chi square, correlations and t-test.

The summary of the analysis results is as follows: 
i. It is suggested that the null hypothesis, H0 (transformational leadership of high school managers is not significantly related to affective commitment of high school teachers in Istanbul), can be rejected in favor of the alternate hypothesis, H1 (transformational leadership of high school managers is significantly related to affective commitment of high school teachers in Istanbul) because the significance value $(0.000)$ is less than the usual threshold value of 0.05 according to the chi square frequencies output.

ii. A significant positive relationship between transformational leadership and affective commitment is found (Sig. 2-tailed level is .000) through correlations result.

iii. Null hypothesis is rejected, since $\mathrm{p}<0.05$ according to t-test output.

A strong evidence found that $(\mathrm{p}=0.000)$ transformational leadership of high school managers is related to affective commitment of high school teachers in Istanbul.

The study conducted by Yilmaz \& Cokluk (2010) which investigates the relationship between teachers' organizational commitment and school administrators' leadership behavior found a moderate positive relationship between the teachers' perceptions about organizational commitment and supportive leadership behavior of school administrators which is in line with the results of this study.

The results of the study agree with the findings of Farahani, Taghadosi \& Behboudi (2011) where they found that the relationship between transformational leadership style and organizational commitment is positive and significant in line with this research.

The findings of Batool (2013) also agree with the results of this study in which it is found that the relationship between transformational leadership style and organizational commitment is positive and significant.

Another study is conducted by Bushra et al. (2011) which agrees with the results of the current study. The findings of their study conclude that transformational leadership positively affects job satisfaction and organizational commitment of employees.

\section{REFERENCES}

1. Allen, N.J. \& Meyer, J.P. (1996), 'Affective, Continuance, and Normative Commitment to the Organization: An Examination of Construct Validity', Journal of Vocational Behavior, vol. 49, pp. 255.

2. Angle, H.L. \& J.L. Perry. (1981), ‘An Empirical Assessment of Organizational Commitment and Organizational Effectiveness', Administrative Science Quarterly, vol. 26, p. 3.

3. Avolio, B. J. \& Bass, B. M. (2004). Multifactor Leadership Questionnaire. Manual and sampler set, 3rd edition, Redwood City, CA: Mind Garden.

4. Batool, B. F. (2013), An Empirical Study on Effect of Transformational Leadership on Organizational Commitment in the Banking Sector of Pakistan, Superior university KalmaChowkGulberg Lahore: Punjab Pakistan.

5. Bayram, L. (2005), 'A New Paradigm in Management: Organizational Commitment', Journal of Sayistay, vol. 59, pp. 126-128.

6. Bushra, F., Usman, A. \&Naveed, A. (2011), Effect of Transformational Leadership on Employees' Job Satisfaction and Organizational Commitment in Banking Sector of Lahore (Pakistan),Hailey College of Commerce, University of the Punjab, Lahore, Pakistan.

7. Cemaloglu, N. (2007), 'Okul Yöneticilerinin Liderlik Stillerinin Örgüt Sağlığı Üzerindeki Etkisi', Türkiye Sosyal Araştırmalar Dergisi, 11(2), pp. 165-194.

8. Cengiz, A. A. (2000), An Overview of Improvement of Organizational Commitment in the Information Age, Eskisehir: Anadolu University, pp. 513-514.

9. Col, G. (2004), 'The Concept of Organizational Commitment and its Relation with Similar Concepts', Industrial Relations and Human Resources Journal, p. 2.

10. Eren, E. (1998), Organizational Behavior and Managerial Psychology, 5th edition, pp. 342-369.

11. Farahani, M., Taghadosi M. \&Behboudi M. (2011), An Exploration of the Relationship between Transformational Leadership and Organizational Commitment: The Moderating Effect of Emotional Intelligence: Case Study in Iran, School of Management and Accountancy, Islamic Azad University Qazvin Branch.

12. Iscan, O.F. (2002), Transformational Leadership in Global Management, PhD Thesis, Ataturk University.

13. Meyer, J. P., Allen, N. J. \& Smith, C. A. (1993), 'Commitment to Organizations and Occupations: Extension and Test of a Three-component Conceptualization.', Journal of Applied Psychology, 78(4), pp. 538-551.

14. Saglam, E. (2008), The Relationship between Leadership Style of Managers and Personality,Yeditepe University, Educational Sciences Institute, Master's Thesis, pp. 202-204.

15. Slocombe, T.E. \& Dougherty, T.W. (1998), 'Dissecting Organizational Commitment and Its relationship with Employee Behavior', Journal of Business and Psychology, vol. 12, no. 4, p. 469.

16. Suliman, A.M. \& Iles, P.A. (2000), 'The MultiDimensional Nature of Organizational Commitment in a Non-Western Context', Journal of Management Development, vol. 19, no. 1, pp. 71-82.

17. Tayyah, S. \& Tariq, N. (2001), 'Development of an Indigenous Organizational Commitment Questionnaire: Pakistan Journal of Psychological Research', ProQuest Psychology Journals, vol. 16, no. 1/2, p. 31. 
57 G. Demir/ Southeast Europe Journal of Soft Computing Vol.5 No.1 March 2016 (51-57)

18. Tichy, N. (1996), 'Simultaneous Transformation and CEO Succession: Key to Global Competitive', Organizational Dynamics, p. 46.

19. Yilmaz, K. \&Cokluk, O. (2010), 'The Relationship between Leadership Behavior and Organizational Commitment in Turkish Primary Schools', Bilig Journal, no. 54 , pp. $75-92$. 